\title{
Contribution of corn intercropped with Brachiaria species to nutrient cycling ${ }^{1}$
}

\author{
Silas Maciel de Oliveira², Rodrigo Estevam Munhoz de Almeida ${ }^{3}$, \\ Clovis Pierozan Junior ${ }^{4}$, André Fróes de Borja Reis ${ }^{5}$, Lucas Freitas Nogueira Souza ${ }^{5}$, José Laércio Favarin ${ }^{5}$
}

\begin{abstract}
The corn biomass and nutrient dynamics may be altered when it is intercropped with Brachiaria (syn. Urochloa spp.). The present study aimed to investigate the dynamics of biomass, nitrogen $(\mathrm{N})$, phosphorus $(\mathrm{P})$ and potassium $(\mathrm{K})$ for farming systems that produce corn intercropped with Brachiaria species. Field experiments were performed during the season and off-season, in a split-plot design. The main plots were composed of Brachiaria species (B. brizantha, B. ruziziensis and $B$. Convert) intercropped with corn, in addition to corn monocropping. The subplots consisted of three forage sampling periods, ranging from 0 to 60 days after the corn harvest. The intercropping arrangements did not affect the corn grain yield, nutrient accumulation and partitioning, relatively to the corn monocropping. After the grain harvest, B. brizantha achieved the greater biomass accumulation rate in both the season $\left(69 \mathrm{~kg} \mathrm{ha}^{-1}\right.$ day $\left.^{-1}\right)$ and off-season $\left(17 \mathrm{~kg} \mathrm{ha}^{-1} \mathrm{day}^{-1}\right)$. The nutrient accumulation ranged widely between the Brachiaria species and planting seasons: $0.2-1.2 \mathrm{~kg} \mathrm{ha}^{-1} \mathrm{day}^{-1}$ for $\mathrm{N}$; 0.01-0.07 kg ha ${ }^{-1}$ day $^{-1}$ for P; and 0.13-0.8 $\mathrm{kg} \mathrm{ha}^{-1}$ day $^{-1}$ for $\mathrm{K}$. However, the greatest nutrient accumulation was found for $B$. brizantha, followed by B. ruziziensis and then $B$. Convert. In the short-term, corn intercropped with Brachiaria in the season showed the largest effect on the nutrient cycling and biomass yield. The intercropping between corn and B. brizantha in the season was the best way to enhance the biomass yield and the $\mathrm{N}, \mathrm{P}$ and $\mathrm{K}$ cycling.
\end{abstract}

KEYWORDS: Zea mays L., Urochloa spp., nutrient balance, forage plants.

\section{INTRODUCTION}

Cover crops have been included in crop rotation to meet challenges such as the deterioration of soil physical traits and nutrient losses. Overall,

\section{RESUMO}

Contribuição de milho consorciado com espécies de Brachiaria na ciclagem de nutrientes

A dinâmica de biomassa e nutrientes do milho pode ser alterada quando consorciado com Brachiaria (syn. Urochloa spp.). Objetivou-se investigar a dinâmica de biomassa, nitrogênio $(\mathrm{N})$, fósforo $(\mathrm{P})$ e potássio $(\mathrm{K})$ para sistemas de produção de milho consorciado com espécies de Brachiaria. Campos experimentais foram conduzidos durante a safra e safrinha, em esquema de parcelas subdivididas. As parcelas principais foram compostas por espécies de braquiária (B. brizantha, B. ruziziensis, e $B$. Convert) consorciadas com milho, além de monocultivo de milho. As subparcelas consistiram de períodos de amostragem da forragem, variando de 0 a 60 dias após a colheita do milho. O consórcio não afetou a produtividade de grãos, acúmulo e partição de nutrientes no milho. Após a colheita de grãos, $B$. brizantha obteve a maior taxa de acúmulo de biomassa na safra $\left(69 \mathrm{~kg} \mathrm{ha}^{-1} \mathrm{dia}^{-1}\right)$ e safrinha $\left(17 \mathrm{~kg} \mathrm{ha}^{-1} \mathrm{dia}^{-1}\right)$. O acúmulo de nutrientes variou amplamente entre as espécies de Brachiaria e estação de cultivo: 0.2-1.2 $\mathrm{kg} \mathrm{ha}^{-1} \mathrm{dia}^{-1}$ para N; 0.01-0.07 kg ha-1 dia-1 para P; e 0.13-0.8 $\mathrm{kg} \mathrm{ha}^{-1}$ dia $^{-1}$ para $\mathrm{K}$. Contudo, o maior acúmulo de nutrientes foi registrado para $B$. brizantha, seguida de $B$. ruziziensis e $B$. Convert. A curto prazo, o milho consorciado com Brachiaria na safra obteve maior efeito sobre a ciclagem de nutrientes e produção de biomassa. $\mathrm{O}$ consórcio entre milho e $B$. brizantha na safra foi a melhor opção para aumentar a produção de biomassa e a ciclagem de N, P e K.

PALAVRAS CHAVE: Zea mays L., Urochloa spp., balanço de nutrientes, plantas forrageiras.

cover crops contribute to the recovery and cycling of nutrients, reduce the risk of soil erosion and assist in controlling pests, diseases and nematodes (Leandro \& Asmus 2015, Ren et al. 2019, Tanaka et al. 2019).

1. Received: Sep. 18, 2018. Accepted: May 28, 2019. Published: Jul. 23, 2019. DOI: 10.1590/1983-40632019v4955018.

2. Universidade Estadual de Maringá, Departamento de Agronomia, Maringá, PR, Brasil. E-mail/ORCID: smoliveira2@uem.br/0000-0002-1162-2994.

3. Empresa Brasileira de Pesquisa Agropecuária (Embrapa Pesca e Aquicultura), Palmas, TO, Brasil. E-mail/ORCID: rodrigo.almeida@embrapa.br/0000-0002-3675-1661.

4. Instituto Federal do Paraná, Palmas, PR, Brasil.E-mail/ORCID: clovis.junior@ifpr.edu.br/0000-0002-0308-3572.

5. Universidade de São Paulo, Escola Superior de Agricultura Luiz de Queiroz, Departamento de Produção Vegetal, Piracicaba, SP, Brasil.E-mail/ORCID: andrefbr@usp.br/0000-0002-3742-8428, lucas.freitas.souza@usp.br/0000-0001-6188-7926, favarin.esalq@usp.br/0000-0003-0556-9397. 
Under the tropical and subtropical conditions of Brazil, intercropping corn and perennial grasses of the Brachiaria genus is an excellent alternative for establishing Brachiaria as a cover crop (Pariz et al. 2016, Almeida et al. 2017a). To investigate the competition between corn and Brachiaria species, studies have assessed the nutrient balance in the intercropping period, in relation to the plating period, plant density and corn maturity ratings (Borghi et al. 2013, Ceccon et al. 2013, Crusciol et al. 2013). Nonetheless, little attention has been given to the nutrient accumulation and partitioning after the corn harvesting, especially among Brachiaria species.

Some researchers have reported that the biomass and nutrient accumulation in the monocropping of Brachiaria species are affected by agricultural practices, such as the establishment method and forage planting period (Cruz et al. 2008, Pariz et al. 2010). However, the biomass and nutrient accumulation among Brachiaria species intercropped with corn remain poorly understood. Besides the effects of corn on the Brachiaria growth in the intercropping period, the biomass and nutrient accumulation could also be regulated by the planting season.

Most of the areas cultivated with corn, in Brazil, have been planted using intensive cropping systems in the off-season, often following the early cycle soybean [Glycine max (L.) Merr.] harvest. In short, later plantings of corn and Brachiaria expose the crop to a lower availability of rainfall, solar radiation and time available for forage vegetation after the corn harvesting.

The soil nutrient availability, biomass accumulation and growing period have been known to affect the cover crops nutrient cycling (Fageria et al. 2005, Lorin et al. 2016). A better understanding of the amount of nutrients accumulated by Brachiaria species is important for determining the benefits of nutrient cycling and soil fertility. Following this perspective, this study aimed to evaluate the accumulation and partitioning of biomass nitrogen $(\mathrm{N})$, phosphorus $(\mathrm{P})$ and potassium $(\mathrm{K})$ in corn and Brachiaria species intercropped both in the season and off-season, as well as to verify the potential of nutrient cycling after the corn harvesting, given that intercropping benefits are closely associated with biomass and nutrient accumulation by the forage species.

\section{MATERIAL AND METHODS}

Two field trials were carried out throughout the 2014/2015 growing season, in Brazil. The season experiment was carried out in Taquarituba, São Paulo state $\left(23^{\circ} 35^{\prime} 14.1^{\prime \prime} \mathrm{S}, 49^{\circ} 14^{\prime} 55.2^{\prime \prime} \mathrm{W}\right.$ and altitude of $630 \mathrm{~m}$ ). The soil of the area is classified as a Hapludalf (USDA 1998) or Nitossolo (Santos et al. 2013), with $657 \mathrm{~g} \mathrm{~kg}^{1}$ of clay, $253 \mathrm{~g} \mathrm{~kg}^{1}$ of silt and $90 \mathrm{~g} \mathrm{~kg}^{1}$ of sand. The off-season experiment was conducted in Maringá, Paraná state $\left(23^{\circ} 17^{\prime} 41.9^{\prime \prime S}, 51^{\circ} 53^{\prime} 31.0\right.$ "W and altitude of $515 \mathrm{~m}$ ). The soil is classified as an Oxisoil (USDA 1998) or Latossolo (Santos et al. 2013), with $541 \mathrm{~g} \mathrm{~kg}^{-1}$ of clay, $289 \mathrm{~g} \mathrm{~kg}^{-1}$ of silt and $170 \mathrm{~g} \mathrm{~kg}^{-1}$ of sand. According to the Köppen classification updated by Alvares et al. (2013), both the regions have a Cfa climate, characterized as humid subtropical, with hot summers. The weather data were collected during the experimental period (Figure 1).

The soil (0.0-0.2 $\mathrm{m}$ of depth) chemical composition was analyzed before the beginning of the experiment. The results for the season and offseason were, respectively, $\mathrm{pH}$ in $\mathrm{CaCl}_{2}$ of 5.3 and 6.3 , soil organic matter of $24 \mathrm{~g} \mathrm{dm}^{-3}$ and $18 \mathrm{~g} \mathrm{dm}^{-3}$, $\mathrm{P}$ (resin extractor) of $24 \mathrm{~g} \mathrm{dm}^{-3}$ and $30 \mathrm{mg} \mathrm{dm}^{-3}, \mathrm{~K}$

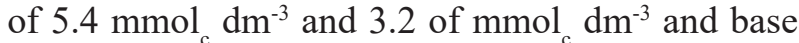
saturation of $61 \%$ and $84 \%$.

The trials were performed in a split-plot randomized block design, with four treatments for the main plots and three treatments for the subplots, with five replications. The farming systems consisted of corn monocropping and three forage grasses of the Brachiaria (syn. Urochloa) genus intercropped with corn: Brachiaria hybrid Mulato II (Convert HD 364) cultivar, B. brizantha cv. Marandu and B. ruziziensis. The subplots consisted of three forage biomass collection periods after the corn harvesting, which were 0 days after harvesting (DAH), when samples were taken at the corn harvesting, $30 \mathrm{DAH}$ and $60 \mathrm{DAH}$ for the season; and $0 \mathrm{DAH}, 30 \mathrm{DAH}$ and $45 \mathrm{DAH}$ for the off-season (Figure 1). The third collection in the off-season was not performed at 60 DAH because the area was being prepared for soybean planting at the season.

Where corn was planted in the season, the area had been previously cultivated for 15 years with B. brizantha pasture and in the last 5 years with cash crops such as soybean, corn, sorghum and oats, in a no-tillage system. Planting occurred on 12 November 2014, on black oat residues (Avena strigosa). Where 

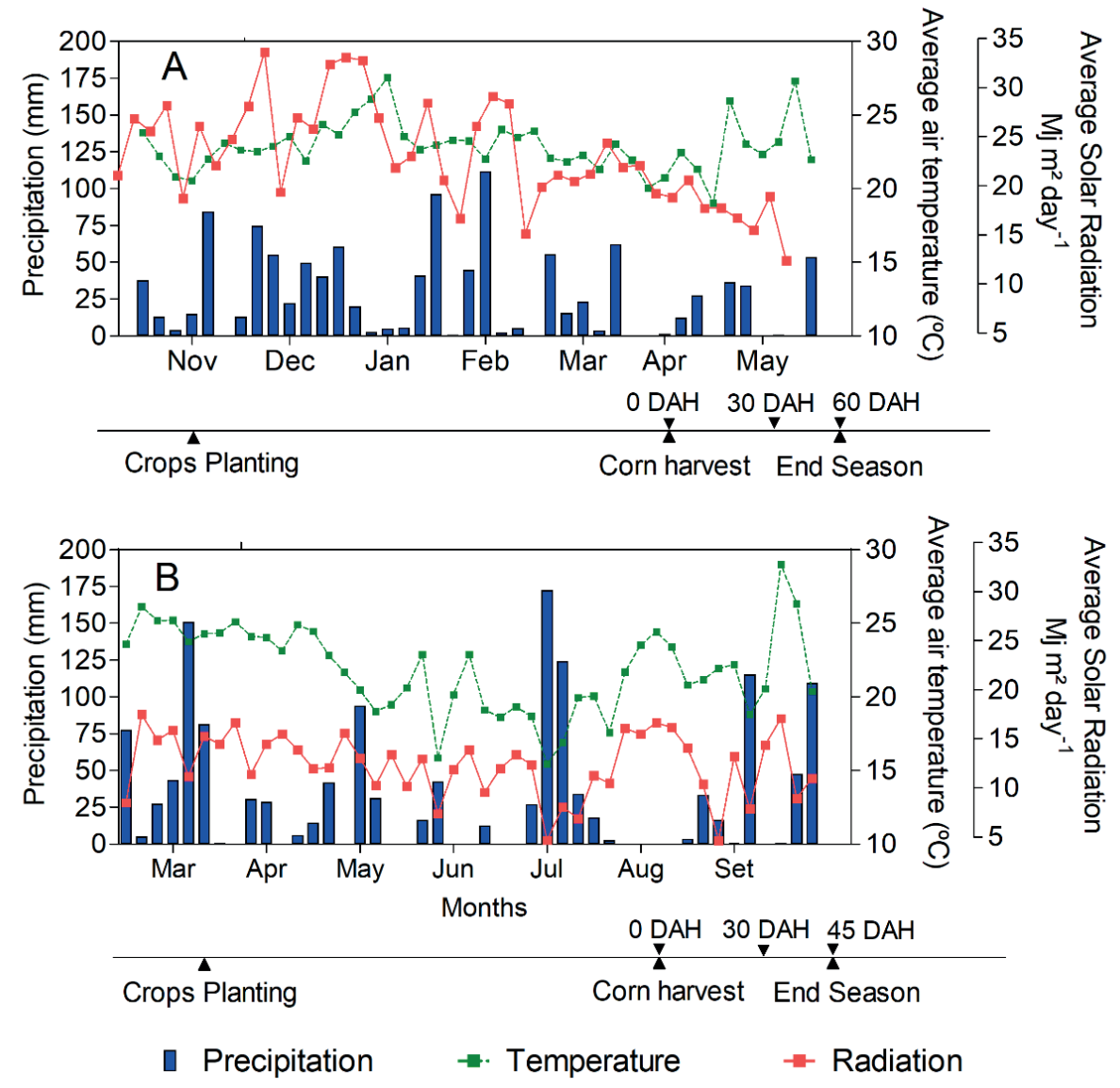

Figure 1. Planting date, precipitation, average air temperature and solar radiation during the study period for the season of 2014 (A) and off-season of 2015 (B). The crops planting, corn harvest and end season indicated the planting data of both the corn and forage crops, corn grains harvest and last forage sampling, respectively. DAH: days after harvest.

corn was sown off-season, the experimental area had been used since 2006 under no-tillage management and with soybean, corn and wheat crop rotation. Planting occurred on 2 March 2015, on soybean residues. The $30137 \mathrm{HX}$ and $\mathrm{B} 188$ corn hybrids were planted in the season and off-season, both at a density of 60,000 plants ha ${ }^{-1}$ and a row spacing of $0.9 \mathrm{~m}$. Brachiaria species were planted on the same day as the corn. Planting was performed manually in 5-cm deep furrows between the corn rows and with $4.5 \mathrm{~kg} \mathrm{ha}^{-1}$ of viable seeds. All plots received $640 \mathrm{~g} \mathrm{ha}^{-1}$ of glyphosate acid equivalent before sowing for weed control. Then, 3,250 g a.i. ha ${ }^{-1}$ of atrazine and $25 \mathrm{~g}$ a.i. ha ${ }^{-1}$ of nicosulfuron were applied in post-emergence, when the Brachiaria species issued the first tiller for the monocropping and intercropping arrangements.

In the planting time, $50 \mathrm{~kg} \mathrm{ha}^{-1}$ of $\mathrm{P}_{2} \mathrm{O}_{5}$ were applied as triple superphosphate and $50 \mathrm{~kg} \mathrm{ha}^{-1}$ of $\mathrm{K}_{2} 0$ as $\mathrm{KCl}$. Topdressing mineral fertilizer was applied at the V3 growth stage (Ritchie et al. 1986) by using $150 \mathrm{~kg} \mathrm{ha}^{-1}$ and $120 \mathrm{~kg} \mathrm{ha}^{-1}$ of $\mathrm{N}$ as ammonium sulfate, which were applied as cover in the season and off-season, respectively.

The grain yield was standardized to $13 \%$ of moisture and the corn biomass yield and nutrient contents were obtained from four plants collected in the center of the plots and divided into grains and stover (stem, leaves, cob, tassel and ear wing). Brachiaria samples were obtained by cutting the plants present in a $1-\mathrm{m}^{2}$ area at the ground level, during each sampling period. The biomass yield, N, K and $\mathrm{P}$ values were obtained by the sum of the values of the corn samples obtained in the grain harvest plus the last Brachiaria sampling. In the corn monocropping plots, spontaneous vegetation was also recorded to assess the biomass and nutrient balance. Spontaneous plants were taken from $1-\mathrm{m}^{2}$ areas at the plot center, when the last sampling procedure was performed: 60 and $45 \mathrm{DAH}$ for the season and off-season, respectively. 
The concentration of $\mathrm{N}$ in the plant tissues was determined from Kjeldahl distillation. K and $\mathrm{P}$ concentrations were determined by X-ray fluorescence (EDXRF) (Tezotto et al. 2013), in samples ground to dry and loose powder.

The data underwent tests of normality and homogeneity of variance, followed by analysis of variance by the $\mathrm{F}$ test at $5 \%$ of probability, using the SAS software, version Windows 9. The main plot treatment of the Brachiaria species and corn, collecting period and their interactions were considered the model fixed effects. Each sampling site was independently analyzed. If the null hypothesis was rejected, the Tukey test at $\mathrm{p} \leq 0.05$ and regression analyses were performed for the Brachiaria sampling across the days, after the corn harvest.

\section{RESULTS AND DISCUSSION}

The corn grain yield was not affected by the farming systems, being $6.8 \pm 0.7 \mathrm{Mg} \mathrm{ha}^{-1}$,
$5.7 \pm 0.8 \mathrm{Mgha}^{-1}, 5.8 \pm 0.5 \mathrm{Mgha}^{-1}$ and $7.0 \pm 0.4 \mathrm{Mg} \mathrm{ha}^{-1}$, respectively for corn monocropping, corn- $B$. Convert, corn- $B$. brizantha and corn- $B$. ruziziensis, in the season. For the off-season, the grain yields were $6.5 \pm 0.2 \mathrm{Mg} \mathrm{ha}^{-1}, 6.6 \pm 0.1 \mathrm{Mg} \mathrm{ha}^{-1}$, $6.3 \pm 0.3 \mathrm{Mg} \mathrm{ha}^{-1}$ and $6.6 \pm 0.1 \mathrm{Mg} \mathrm{ha}^{-1}$, respectively for corn monocropping, corn- $B$. Convert, corn- $B$. brizantha and corn- $B$. ruziziensis. In the season, a large population of Spodoptera frugiperda was recorded between V4 and V6, which likely affected all treatments at the same level, although it lowered the mean grain yield of the experimental area.

The dry biomass values for grain, stover and whole plants were not affected by the intercropping system $(p>0.05)$. The total biomass values were 14.5 $\mathrm{Mg} \mathrm{ha}^{-1}$ and 14.7 $\mathrm{Mg} \mathrm{ha}^{-1}$, respectively for the season and off-season (Figure 2).

Intercropping also did not affect the accumulation of nutrients in the corn grains, stover or total biomass $(p>0.05)$, in both the planting seasons. On average, corn accumulated $179 \mathrm{~kg} \mathrm{ha}^{-1}$
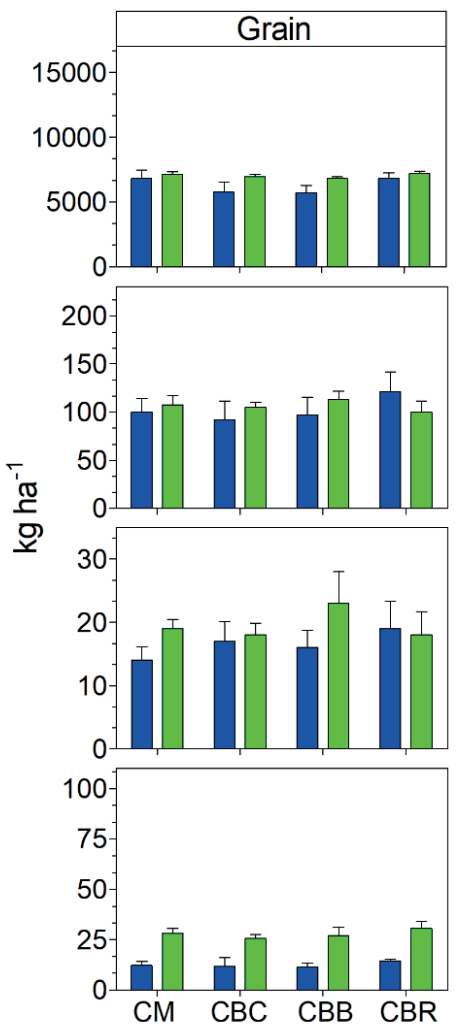
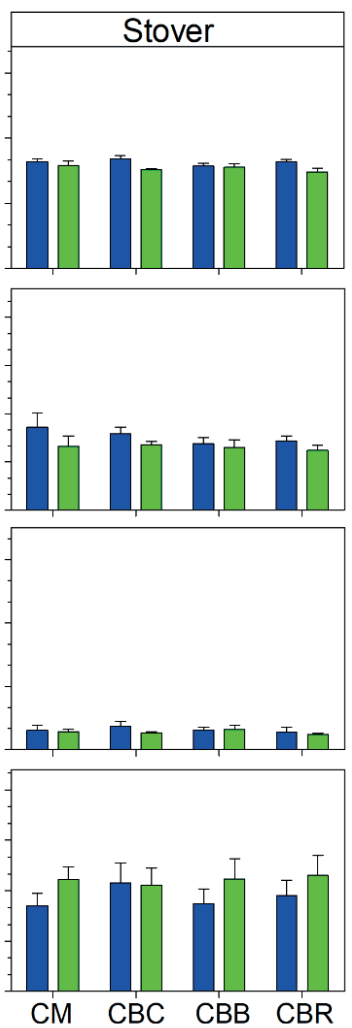
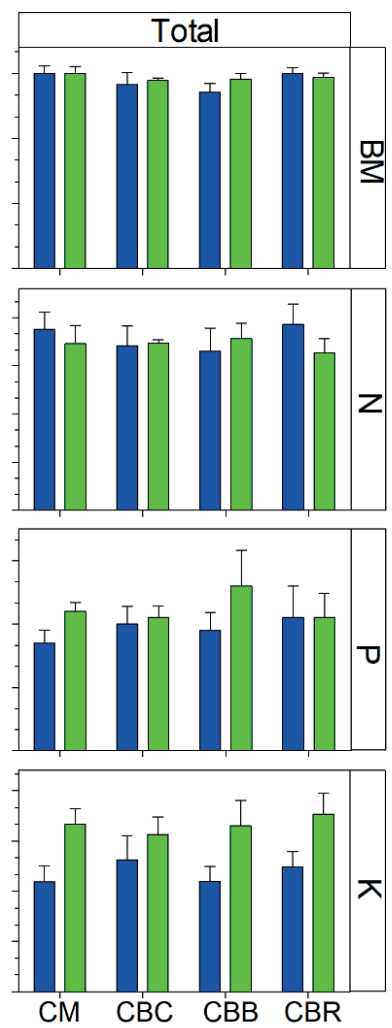

Season

Off-season

Figure 2. Influence of farming systems on biomass $(\mathrm{BM})$, nitrogen $(\mathrm{N})$, phosphorus $(\mathrm{P})$ and potassium $(\mathrm{K})$ and nutrient partitioning in corn. CM: corn monocropping; CBC: corn- $B$. Convert; CBB: corn-B. brizantha; CBR: corn-B. ruziziensis. Vertical bars indicate standard error from the data. 
of N, $20 \mathrm{~kg} \mathrm{ha}^{-1}$ of P and $59 \mathrm{~kg} \mathrm{ha}^{-1}$ of K (Figure 2). In the off-season, corn accumulated $172 \mathrm{~kg} \mathrm{ha}^{-1}$ of $\mathrm{N}, 22 \mathrm{~kg} \mathrm{ha}^{-1}$ of $\mathrm{P}$ and $83 \mathrm{~kg} \mathrm{ha}^{-1}$ of K (Figure 2). Apparently, the $\mathrm{K}$ content recorded in the off-season could be greater. Several factors may affect the K content in corn, but differences between hybrids arise herein as a major effect, since the biomass values were similar.

Besides the lack of effect on corn grain yield, results previously reported by Almeida et al. (2017a, 2017 b), as well as results of the present study, prove that the intercropping did not affect the partition and accumulation of biomass, N, P and K on corn. In some instances, the intercropping between two or more crops resulted in significant effects on the biomass yield and nutrients partitioning ( $\mathrm{Hu}$ et al. 2016, Lowry \& Brainard 2016), but considerable biomass values are registered for both intercropping patterns. In the present study, a low biomass yield $\left(170-1,020 \mathrm{~kg} \mathrm{ha}^{-1}\right)$ was achieved by Brachiaria species from planting at zero days after the corn harvesting (Table 1). Regardless of the growing season, it was not enough to affect the corn and its partitioning dynamics.

In the season, there was a large number of interactions between Brachiaria species and samples (Table 1). However, the accumulation of biomass and nutrients increased in the Brachiaria species throughout the sampling dates (Figure 3). Overall, Brachiaria species affected the biomass production and nutrient accumulation only after the grain harvesting. Starting from zero days after the corn harvesting and using values showed in equations (Figure 3), $66 \mathrm{~kg} \mathrm{ha}^{-1}$ day $^{-1}, 44 \mathrm{~kg} \mathrm{ha}^{-1}$ day $^{-1}$ and $31 \mathrm{~kg} \mathrm{ha}^{-1}$ day $^{-1}$ of accumulated biomass were registered for B. brizantha, B. ruziziensis and $B$. Convert, respectively. Interactions between species and collection dates were recorded for N, P and K (Table 1). B. brizantha was also the species with the greatest nutrient accumulations after the corn harvesting. On average, $B$. brizantha accumulated $1.2 \mathrm{~kg} \mathrm{ha}^{-1}$ day $^{-1}$ of $\mathrm{N}, 0.07 \mathrm{~kg} \mathrm{ha}^{-1}$ day $^{-1}$ of $\mathrm{P}$ and $0.7 \mathrm{~kg} \mathrm{ha}^{-1}$ day $^{-1}$ of $\mathrm{K}$ (Figure 3 ).

Interactions between date sampling and species were also recorded for the off-season. As previously reported for the season, biomass and nutrient accumulations in Brachiaria species increased throughout the sampling dates (Table 1). Overall, B. brizantha accumulated the largest amount of biomass. After the grain harvesting, $17 \mathrm{~kg} \mathrm{ha}^{-1}$ day $^{-1}, 15 \mathrm{~kg} \mathrm{ha}^{-1}$ day $^{-1}$ and $14 \mathrm{~kg} \mathrm{ha}^{-1}$ day $^{-1}$ were respectively accumulated for the B. brizantha, $B$. Convert and B. ruziziensis biomass (Figure 3). On average, $B$. brizantha was the species that most

Table 1. Biomass, N, P and K contents of Brachiaria species in the season and off-season.

\begin{tabular}{|c|c|c|c|c|c|c|c|c|c|}
\hline \multirow{2}{*}{$\begin{array}{l}\text { Days after } \\
\text { harvesting }\end{array}$} & \multirow{2}{*}{$\begin{array}{l}\text { Species/ } \\
\text { seasons }\end{array}$} & \multicolumn{2}{|c|}{ Biomass } & \multicolumn{2}{|c|}{$\mathrm{N}$} & \multicolumn{2}{|r|}{$\mathrm{P}$} & \multicolumn{2}{|c|}{$\mathrm{K}$} \\
\hline & & Season & Off-season & Season & Off-season & Season & Off-season & Season & Off-season \\
\hline \multirow{3}{*}{0} & B. brizantha & 1,020 & 350 & 13.2 & 6.5 & 0.8 & 0.4 & 11.7 & 5.5 \\
\hline & B. Convert & 950 & 170 & 13.4 & 3.3 & 0.7 & 0.2 & 9.9 & 2.4 \\
\hline & B. ruziziensis & 930 & 370 & 13.6 & 7.1 & 0.7 & 0.4 & 11.7 & 5.6 \\
\hline \multirow[t]{2}{*}{ Mean } & & $967 \mathrm{C}$ & $297 \mathrm{C}$ & $13.4 \mathrm{C}$ & $5.6 \mathrm{~B}$ & $0.7 \mathrm{C}$ & $0.3 \mathrm{C}$ & $11.1 \mathrm{~B}$ & $4.5 \mathrm{~B}$ \\
\hline & B. brizantha & 2,030 & 910 & 27.7 & 16.5 & 1.4 & 0.7 & 15.1 & 10.3 \\
\hline \multirow[t]{2}{*}{30} & B. Convert & 1,320 & 560 & 19.2 & 11.5 & 1.1 & 0.6 & 11.1 & 7.1 \\
\hline & B. ruziziensis & 1,810 & 760 & 27.1 & 16.5 & 1.3 & 0.8 & 19.6 & 8.1 \\
\hline \multirow[t]{2}{*}{ Mean } & & $1,720 \mathrm{~B}$ & $740 \mathrm{~B}$ & $24.7 \mathrm{~B}$ & $14.8 \mathrm{~A}$ & $1.3 \mathrm{~B}$ & $0.7 \mathrm{~A}$ & $15.3 \mathrm{~B}$ & $8.5 \mathrm{~A}$ \\
\hline & B. brizantha & 5,020 & 1,080 & 87.5 & 15.7 & 5.4 & 0.9 & 57.4 & 12.4 \\
\hline \multirow[t]{2}{*}{$60 / 45^{\mathrm{T}}$} & B. Convert & 2,800 & 880 & 51.2 & 16.2 & 3.3 & 0.9 & 33.2 & 10.4 \\
\hline & B. ruziziensis & 3,550 & 980 & 68.8 & 16.9 & 3.6 & 1.1 & 44.9 & 12.9 \\
\hline \multicolumn{2}{|l|}{ Mean } & $3,790 \mathrm{~A}$ & $980 \mathrm{~A}$ & $69.2 \mathrm{~A}$ & $16.3 \mathrm{~A}$ & $4.1 \mathrm{~A}$ & $1.0 \mathrm{~A}$ & $45.2 \mathrm{~A}$ & $11.9 \mathrm{~A}$ \\
\hline \multicolumn{3}{|c|}{ Source of variation } & \multicolumn{7}{|c|}{ Anova $\operatorname{Pr}>\mathrm{F}$} \\
\hline \multicolumn{2}{|c|}{ Brachiaria species (BS) } & $*$ & $*$ & $*$ & $*$ & $*$ & $*$ & $*$ & $*$ \\
\hline \multicolumn{2}{|l|}{ Sampling (S) } & $*$ & $*$ & $*$ & $*$ & $*$ & $*$ & $*$ & $*$ \\
\hline \multicolumn{2}{|l|}{$\mathrm{BS} * \mathrm{~S}$} & $*$ & $*$ & $*$ & $*$ & $*$ & $* *$ & $*$ & $*$ \\
\hline \multicolumn{2}{|l|}{ CV (\%) } & 14.11 & 5.6 & 5.6 & 12.3 & 7.1 & 7.8 & 7.9 & 14.6 \\
\hline
\end{tabular}




\section{Season}
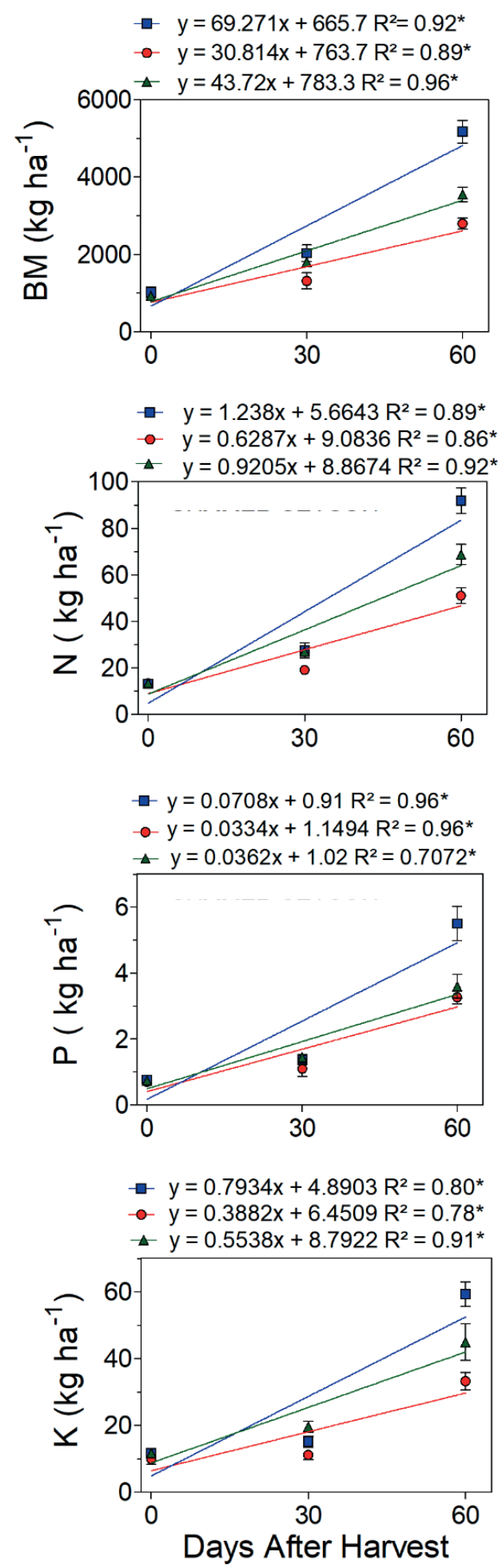

\section{Off-season}
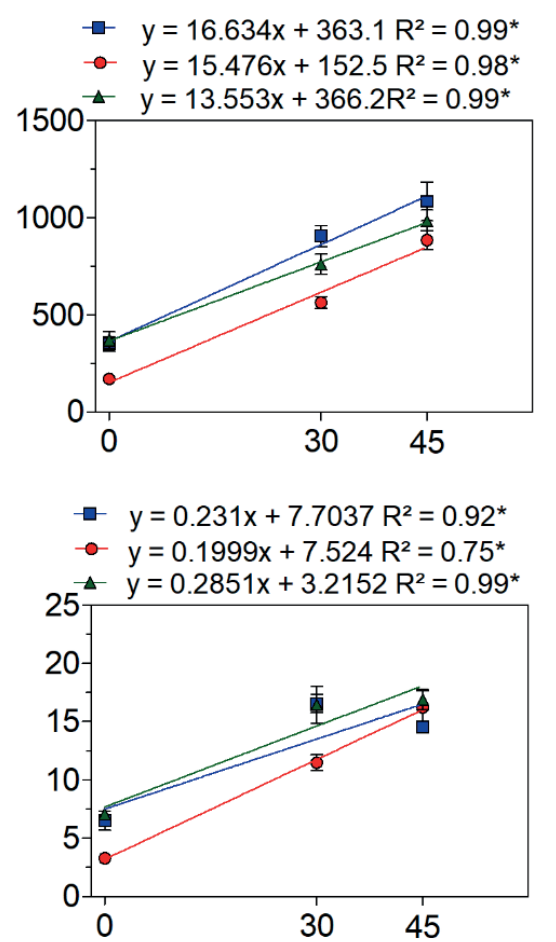

$\rightarrow y=0.015 x+0.393 R^{2}=0.99 *$

$\rightarrow y=0.0123 x+0.3752 R^{2}=0.97^{*}$

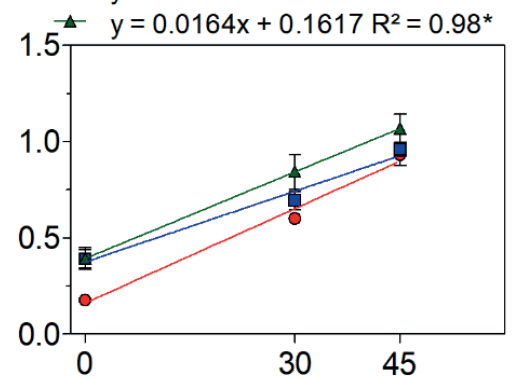

$\rightarrow y=0.151 x+5.0639 R^{2}=0.87^{*}$

$\rightarrow y=0.1297 x+5.7494 R^{2}=0.95^{*}$

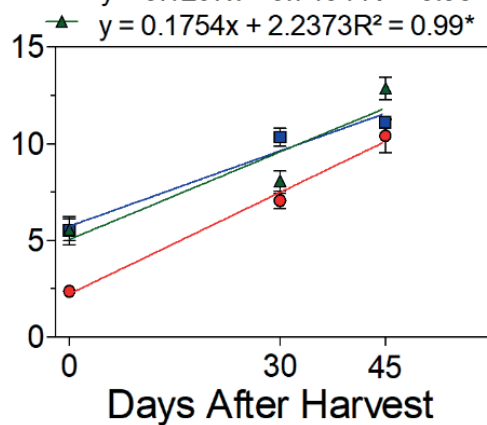

\section{- B.Brizantha ־ B.Convert $\star$ B.Ruziziensis}

Figure 3. Amount of biomass (BM), nitrogen $(\mathrm{N})$, phosphorus $(\mathrm{P})$ and potassium (K) content among the Brachiaria species after the corn harvesting. * Significance at $\mathrm{p}<0.05$. Vertical bars indicate standard error from the data. 
accumulated nutrients: $0.23 \mathrm{~kg} \mathrm{ha}^{-1} \mathrm{day}^{-1}$ of $\mathrm{N}$, $0.015 \mathrm{~kg} \mathrm{ha}^{-1}$ day $^{-1}$ of P and $0.15 \mathrm{~kg} \mathrm{ha}^{-1}$ day $^{-1}$ of $\mathrm{K}$. The nutrient uptake in plants is closely related to the total above ground biomass accumulation. In the present study, because $B$. brizantha showed the highest biomass production, it was also expected that it showed the greater nutrient accumulation.

The biomass accumulation of Brachiaria species in the off-season was potentially lower than in the season, which usually ranged between $50 \mathrm{~kg} \mathrm{ha}^{-1} \mathrm{day}^{-1}$ and $130 \mathrm{~kg} \mathrm{ha}^{-1}$ day $^{-1}$ (Cruz et al. 2008, Crusciol et al. 2013, Almeida et al. 2017a). However, the Brachiaria biomass measured in the present study for the off-season (13-16 kg ha-1 $\left.\mathrm{day}^{-1}\right)$ is in accordance with other authors (3-44 $\mathrm{kg} \mathrm{ha}^{-1}$ day $\left.^{-1}\right)$ (Brambilla et al. 2009, Richart et al. 2010, Batista et al. 2012). Accordingly, the lower biomass, post-harvest nutrient accumulation and nutrient cycling were not enough to affect the balance in the off-season. Nonetheless, all Brachiaria species accumulated more biomass during the post-harvest period than the fallow area proceeded by corn monocropping.

Among the Brachiaria species, B. brizantha had the highest biomass accumulation $\left(66 \mathrm{~kg} \mathrm{ha}^{-1}\right.$ day $^{-1}$ and $17 \mathrm{~kg} \mathrm{ha}^{-1}$ day $^{-1}$ in the season and off-season, respectively). This can be explained by the erect canopy in $B$. brizantha, which allows a higher light interception. Previous studies have also reported a higher biomass and forage yields for $B$. brizantha, if compared to other species of this genus (Pariz et al. 2010, Cabral et al. 2013). Additionally, $B$. brizantha shows a smaller stem elongation rate under shade environments, improving the energy use on leaf spawn and leaf elongation (Pacciullo et al. 2011).

The biomass accumulation and nutrient cycling registered herein with Brachiaria species were close to those reported for annual crops traditionally grown after corn. In a study with common oat (Avena sativa), Hashemi et al. (2013) observed biomass values between $28 \mathrm{~kg} \mathrm{ha}^{-1} \mathrm{day}^{-1}$ and $58 \mathrm{~kg} \mathrm{ha}^{-1} \mathrm{day}^{-1}$, with $\mathrm{N}$ accumulation values between $0.68 \mathrm{~kg} \mathrm{ha}^{-1} \mathrm{day}^{-1}$ and $0.85 \mathrm{~kg} \mathrm{ha}^{-1} \mathrm{day}^{-1}$. These values are similar to those in the range of $1.2 \mathrm{ha}^{-1}$ day $^{-1}$ and $0.62 \mathrm{~kg} \mathrm{ha}^{-1}$ day $^{-1}$ of $\mathrm{N}$ cycled by $B$. brizantha and B. ruziziensis, respectively, in the season (Figure 3). In common oat and white lupine (Lupinus albus), Pissinati et al. (2016) observed a cycling of $0.013-0.026 \mathrm{~kg} \mathrm{ha}^{-1} \mathrm{day}^{-1}$ of $\mathrm{P}$ and $0.12-0.24 \mathrm{~kg} \mathrm{ha}^{-1}$ day $^{-1}$ of $\mathrm{K}$, which are very close to the mean amount accumulated by the
Brachiaria species in this study. These results suggest that corn intercropped with Brachiaria species is an effective farming system to enhance the $\mathrm{N}, \mathrm{P}$ and $\mathrm{K}$ cycling.

In the season, the total biomass and nutrient accumulation were positively affected by the intercropping systems $(\mathrm{p}<0.05)$, except for $\mathrm{N}$. Regarding the corn monocropping, the intercropped systems increased the total biomass $\left(\sim 2,700 \mathrm{~kg} \mathrm{ha}^{-1}\right)$, $\mathrm{N}\left(\sim 53 \mathrm{~kg} \mathrm{ha}^{-1}\right), \mathrm{P}\left(\sim 7 \mathrm{~kg} \mathrm{ha}^{-1}\right)$ and $\mathrm{K}\left(\sim 36 \mathrm{~kg} \mathrm{ha}^{-1}\right)$ (Figure 4).

Most contributions to the biomass yields and P contents came from corn components (Figure 4). Nonetheless, the contribution of B. brizantha to the total $\mathrm{N}$ accumulation in the production system was similar to those of corn components, stover and grain. The B. ruziziensis and B. brizantha species
Season
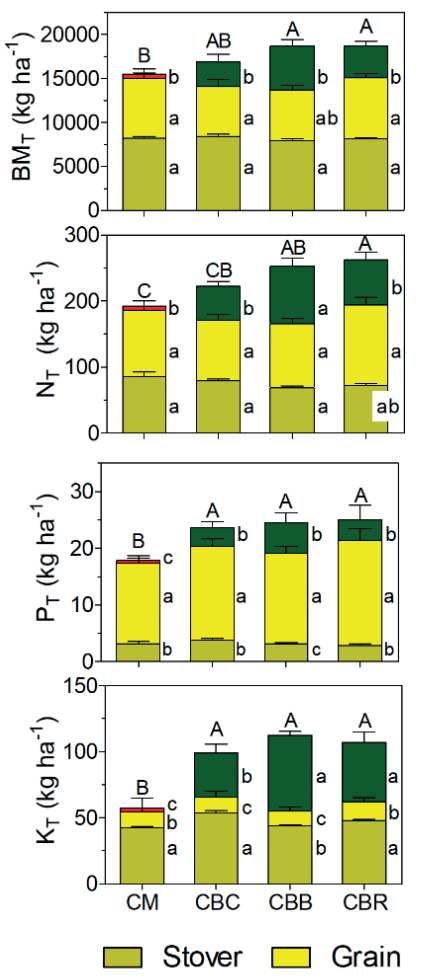

Off-season
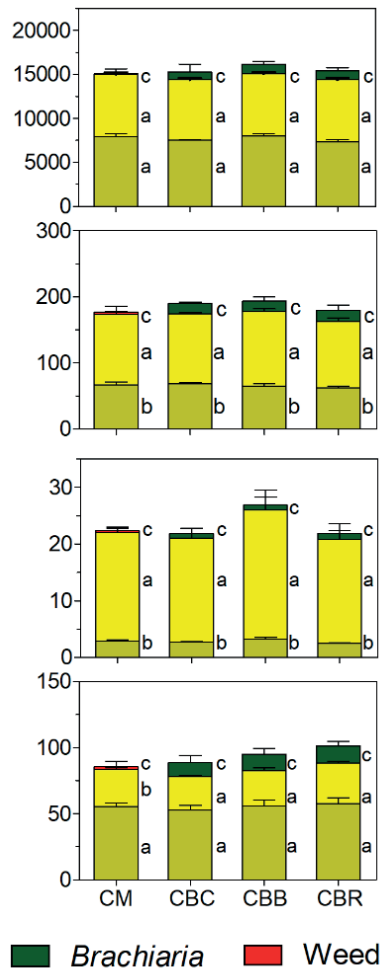

Figure 4. Influence of the farming systems on total (corn and Brachiaria) values of biomass $\left(\mathrm{BM}_{\mathrm{T}}\right)$, nitrogen $\left(\mathrm{N}_{\mathrm{T}}\right)$, phosphorus $\left(\mathrm{P}_{\mathrm{T}}\right)$ and potassium $\left(\mathrm{K}_{\mathrm{T}}\right)$. CM: corn monocropping; $\mathrm{CBC}$ : corn- $B$. Convert; $\mathrm{CBB}$ : corn- $B$. brizantha; CBR: corn- $B$. ruziziensis (CBR). Lowercase letters indicate significant differences $(\mathrm{p}>0.05)$ among the compartments within each farming system; uppercase letters significant differences $(p>0.05)$ among the farming systems; and vertical bars the standard error of the data. 
contributed equally or more, if compared to corn stover, for total $\mathrm{K}$ accumulation. The component with the lowest contribution to the $\mathrm{K}$ accumulation was corn grain.

In the off-season, intercropping did not affect the total accumulation of biomass and nutrients ( $\mathrm{p}>0.05$ ). Overall, $15.5 \mathrm{Mg} \mathrm{ha}^{-1}$ of biomass, $185 \mathrm{~kg} \mathrm{ha}^{-1}$ of N, $24 \mathrm{~kg} \mathrm{ha}^{-1}$ of P and $94 \mathrm{~kg} \mathrm{ha}^{-1}$ of K were accumulated (Figure 4). The contribution of the Brachiaria species to the total biomass and nutrients was the same among the farming systems $(p>0.05)$. Corn stover and grain were the components with the greatest contribution to the biomass and nutrient accumulation in the off-season.

\section{CONCLUSIONS}

1. The Brachiaria species did not affect the biomass and nutrient dynamics in corn during intercropping. Overall, B. brizantha had the greater accumulation of biomass after the grain harvesting;

2. Intercropping between corn and Brachiaria species increased the $\mathrm{N}, \mathrm{P}$ and $\mathrm{K}$ accumulation, relatively to corn monocropping, but only when the intercropping was performed during the season;

3 . In corn production systems, the intercropping between corn and Brachiaria is a viable alternative for increasing the post-harvest biomass of corn, and thus it could provide significant benefits to the $\mathrm{N}$ and $\mathrm{K}$ cycling. The establishment of intercropping with $B$. brizantha during the season was the best approach to increase the biomass yield, as well as the N, P and K cycling.

\section{REFERENCES}

ALMEIDA, R. E. M. de et al. Effects of nitrogen fertilization on yield components in a corn-palisadegrass intercropping system. Australian Journal of Crop Science, v. 11, n. 3, p. 352-360, 2017a.

ALMEIDA, R. E. M. de et al. Palisadegrass effects on $\mathrm{N}$ fertilizer dynamic in intercropping systems with corn. Anais da Academia Brasileira de Ciências, v. 89, n. 3, p. 1917-1923, 2017b.

ALVARES, C. A. et al. Köppen's climate classification map for Brazil. Meteorologische Zeitschrift, v. 22, n. 7, p. 711-728, 2013.

BATISTA, K. et al. Acúmulo de matéria seca e de nutrientes em forrageiras consorciadas com milho safrinha em função da adubação nitrogenada. Pesquisa Agropecuária Brasileira, v. 46, n. 10, p. 1154-1160, 2012.

BORGHI, E. et al. Effects of row spacing and intercrop on maize grain yield and forage production of palisade grass. Crop and Pasture Science, v. 63, n. 12, p. 1106-1113, 2013.

BRAMBILLA, J. A. et al. Produtividade de milho safrinha no sistema de integração lavoura-pecuária, na região de Sorriso, Mato Grosso. Revista Brasileira de Milho e Sorgo, v. 8, n. 3, p. 263-274, 2009.

CABRAL, C. E. A. et al. Production efficiency and nitrogen concentration in palisadegrass, signalgrass and convertgrass submitted to nitrogen. Bioscience Journal, v. 29, n. 5 , p. 1653-1664, 2013.

CECCON, G. et al. Legumes and forage species sole or intercropped with corn in soybean-corn succession in midwestern Brazil. Revista Brasileira de Ciência do Solo, v. 37, n. 1, p. 204-212, 2013.

CRUSCIOL, C. A. C. et al. Effect of intercropping on yields of corn with different relative maturities and palisadegrass. Agronomy Journal, v. 105, n. 3, p. 599606, 2013.

CRUZ, S. C. et al. Nutrição do milho e da Brachiaria decumbens cultivados em consórcio em diferentes preparos do solo. Acta Scientiarum Agronomy, v. 30, n. 5 , p. 733-739, 2008.

FAGERIA, N.; BALIGAR, V.; BAILEY, B. Role of cover crops in improving soil and row crop productivity. Communications in Soil Science and Plant Analysis, v. 36, n. 19-20, p. 2733-2757, 2005.

HASHEMI, M. et al. Cover-crop seeding-date influence on fall nitrogen recovery. Journal of Plant Nutrition and Soil Science, v. 176, n. 1, p. 69-75, 2013.

HU, F. et al. Boosting system productivity through the improved coordination of interspecific competition in maize/pea strip intercropping. Field Crops Research, v. 198, n. 1, p. 50-60, 2016.

LEANDRO, H. M.; ASMUS, G. L. Crop rotation and crop sequences for the management of reniform nematode in area of soybean production. Ciência Rural, v. 45, n. 6 , p. 945-950, 2015.

LORIN, M. et al. Undersowing winter oilseed rape with frost-sensitive legume living mulch: consequences for cash crop nitrogen nutrition. Field Crops Research, v. 193, n. 1, p. 24-33, 2016.

LOWRY, C. J.; BRAINARD, D. C. Strip-intercropping of rye-vetch mixtures affects biomass, carbon/nitrogen ratio, and spatial distribution of cover crop residue. Agronomy Journal, v. 108, n. 6, p. 2433-2443, 2016. 
PACIULLO, D. S. C. et al. The growth dynamics in Brachiaria species according to nitrogen dose and shade. Revista Brasileira de Zootecnia, v. 40, n. 2, p. 270-276, 2011.

PARIZ, C. M. et al. Massa seca e composição bromatológica de quatro espécies de braquiárias semeadas na linha ou a lanço, em consórcio com milho no sistema plantio direto na palha. Acta Scientiarum Animal Sciences, v. 32, n. 6, p. 147-154, 2010.

PARIZ, C. M. et al. Production and soil responses to intercropping of forage grasses with corn and soybean silage. Agronomy Journal, v. 108, n. 6, p. 2541-2553, 2016.

PISSINATI, A.; MOREIRA, A.; SANTORO, P. Biomass yield and nutrients concentration in shoot dry weight of winter cover crops for no-tillage systems. Communications in Soil Science and Plant Analysis, v. 47, n. 20, p. 22922305, 2016.

REN, L. et al. Short-term effects of cover crops and tillage methods on soil physical properties and maize growth. Soil and Tillage Research, v. 192, n. 1, p. 76-86, 2019.
RICHART, A. et al. Desempenho do milho safrinha e da Brachiaria ruziziensis cv. Comum em consórcio. Revista Brasileira de Ciências Agrárias, v. 5, n. 4, p. 497-502, 2010.

RITCHIE, S.; HANWAY, J.; BENSON, G. How a plant crop develops. Ames: Iowa State University Repository, 1986.

SANTOS, H. G. et al. Sistema brasileiro de classificação de solos. 3. ed. Brasília, DF: Embrapa, 2013.

TANAKA, K. S. et al. Nutrients released by Urochloa cover crops prior to soybean. Nutrient Cycling in Agroecosystems, v. 113, n. 3, p. 267-281, 2019.

TEZOTTO, T. et al. Simple procedure for nutrient analysis of coffee plant with energy dispersive X-ray fluorescence spectrometry (EDXRF). Scientia Agricola, v. 70, n. 4, p. 263-267, 2013.

UNITED STATES DEPARTMENT OF AGRICULTURE (USDA). Keys to soil taxonomy. Washington, DC: USDA, 1999. 